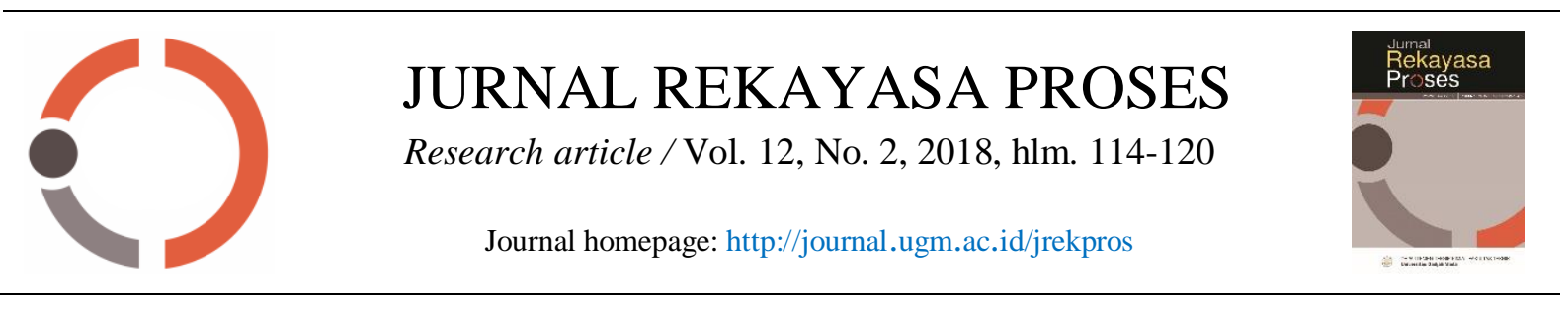

\title{
Kajian Transpor Kreatinin Menggunakan Membran Kitosan-Alginat Tertaut Silang Polivinil Alkohol (PVA)
}

\author{
Ni Putu Sri Ayuni ${ }^{1 *}$, Ni Wayan Yuningrat ${ }^{2}$ dan Ni Wayan Citra $^{2}$ \\ ${ }^{1}$ Program Studi Kimia, FMIPA, Universitas Pendidikan Ganesha \\ Jalan Udayana No 11, Singaraja, 81116 \\ ${ }^{2}$ Program Studi Analis Kimia, FMIPA Universitas Pendidikan Ganesha \\ Jalan Udayana No 11, Singaraja, 81116 \\ *Alamat korespondensi: nps.ayuni@gmail.com
}

(Submisi 29 Agustus 2018 ; Revisi 24 Oktober 2018 ; Penerimaan 24 Oktober 2018)

\section{A B S T R A C T}

The objective of this research was to determine the efficiency of the creatinine transport using chitosan alginate cross linked by polyvinyl alcohol (PVA) $0.1 \%$ with 70,100 , and $130 \mathrm{mg} / \mathrm{L}$ of creatinine concentration. The subject of this study was the membranes of chitosan alginate PVA, while the object of this study was the efficiency of the creatinine transport. The PVA $0.1 \%$ cross-linking chitosan-alginate membrane (1:0.15) was successfully synthesized. The membrane synthesized was characterized by FTIR, as well as tensile and strain test. The FTIR spectra showed that there is a new peak of the amino group of chitosan and carboxyl group of alginate at ca. $1651 \mathrm{~cm}^{-1}$. The hydroxyl group appears at ca. $1088 \mathrm{~cm}^{-1}$ while ester groups at ca. $1088 \mathrm{~cm}^{-1}$ and ca. $1265 \mathrm{~cm}^{-1}$ which indicate the cross binding between alginate and PVA. The water uptake test of the chitosan alginate PVA membrane reaches $257.76 \%$ for 6 hours. The tensile test results of the membrane before and after creatinine transport are $2.77 \mathrm{MPa}$ and $12.56 \mathrm{MPa}$ while the strain tests yield $14.24 \%$ and $18.51 \%$, respectively. The maximum efficiency of the creatinine transport using the chitosan-alginate cross linked by PVA is $51.02 \%$ at $130 \mathrm{mg} / \mathrm{L}$ creatinine. This creatinine transport result using the PVA cross linking chitosan-alginate membrane are more efficient than chitosan-pectin membrane $(25.24 \%)$ with the same creatinine concentration.

Keywords: creatinine, chitosan-alginate PVA membrane, transport, synthesis, cross-link.

\section{A B S T R A K}

Penelitian ini bertujuan untuk menentukan nilai efisiensi transpor kreatinin menggunakan membran kitosan-alginat tertaut silang polivinil alkohol (PVA) 0,1\% dengan konsentrasi kreatinin 70, 100 dan $130 \mathrm{mg} / \mathrm{L}$. Subjek dalam penelitian ini adalah membran kitosan-alginat PVA, sedangkan objek penelitian ini adalah pengaruh efisiensi transpor pada variasi konsentrasi kreatinin. Membran kitosan alginat $(1: 0,15)$ tertaut silang PVA 0,1\% telah berhasil disintesis. Karakterisasi membran kitosanalginat tertaut silang PVA diperoleh untuk spektra FTIR membran menunjukkan bahwa telah terjadi pergeseran serapan gugus amino dari kitosan dan gugus karboksil dari alginat pada puncak sekitar $1651 \mathrm{~cm}^{-1}$. Pada bilangan gelombang $3363,86 \mathrm{~cm}^{-1}$ terdapat serapan gugus $-\mathrm{OH}$ serta pada bilangan gelombang sekitar $1088 \mathrm{~cm}^{-1}$ dan $1265 \mathrm{~cm}^{-1}$ berasal dari gugus ester yang menunjukkan ikatan silang antara alginat dan PVA. Hasil uji serapan air pada membran kitosan-alginat PVA selama 6 jam mencapai rata-rata $257,76 \%$. Hasil uji tarik membran sebelum dan setelah transpor masing-masing: 2,77 MPa dan 12,56 MPa dan untuk hasil uji regang membran sebelum dan setelah transpor masingmasing: $14,24 \%$ dan $18,51 \%$. Efisiensi transpor kreatinin pada membran kitosan-alginat tertaut silang 
PVA mencapai efisiensi transpor maksimal pada konsentrasi $130 \mathrm{mg} / \mathrm{L}(51,02 \%)$. Efisiensi transpor kreatinin ini lebih tinggi jika dibandingkan menggunakan membran kitosan-pektin $(25,24 \%)$ pada konsentrasi yang sama.

Kata kunci: kreatinin, membran kitosan-alginat PVA, sintesis, transpor,taut silang.

\section{Pendahuluan}

Pada orang sehat ginjal merupakan organ utama yang berfungsi menyaring zat sisa-sisa metabolisme tubuh yang harus dikeluarkan melalui ekskresi (Vanholder dkk., 1992). Penyakit Gagal Ginjal Kronik (GGK) merupakan tahapan akhir ginjal ketika Glomerular Filtration Rate atau GFR $<5 \mathrm{~mL}$, sehingga tubuh gagal untuk mempertahankan metabolisme dan keseimbangan cairan dan elektrolit (Ignatavicius, 2006). Akibatnya akan terjadi uremia yaitu penumpukan ureum dan kreatinin dalam darah yang akan mempengaruhi seluruh sistem tubuh. Salah satu cara yang digunakan untuk mengeluarkan senyawa toksin uremat pada penderita gagal ginjal dengan terapi hemodialisis atau cuci darah (Morti dkk., 2003).

Hemodialisis merupakan suatu metode biomedis untuk menggantikan fungsi ginjal dalam proses pembuangan senyawa-senyawa sisa metabolisme keluar dari dalam tubuh. Prinsip utama dari hemodialisis ini adalah difusi partikel melewati suatu membran semipermeabel yang merupakan elemen terpenting dalam alat hemodialisis (Amiji, 1995).

Membran adalah lapisan tipis selektif dan semipermeabel terletak antara dua fase, fase sumber mengandung komponen yang tertahan, dan fase akseptor yang mengandung komponen yang dapat melewati membran. Transportasi melalui membran dicapai karena gradien konsentrasi di kedua fase. Permeabilitas sifat membran berarti bahwa membran dapat memblokir spesies tertentu yang lebih besar dari ukuran pori membran, dan melewati spesies dengan ukuran yang lebih kecil. Sifat selektif membran dapat digunakan dalam proses pemisahan. Untuk digunakan dalam proses hemodialisis, membran harus: (1) memiliki permeabilitas tinggi, yang berarti bahwa membran dapat mengangkut metabolit secepat mungkin dan (2) menjadi hemokompatibel atau tidak ditolak oleh darah (Deppisch dkk., 1998).

Pada saat ini penelitian tentang pemanfaatan polimer alam sebagai membran khususnya untuk hemodialisis sedang dikembangkan. Kitosan dipilih sebagai material awal pembuatan membran karena keberadaannya yang cukup melimpah di muka bumi dan merupakan biopolimer terbesar kedua setelah selulosa. Membran dengan berbahan dasar kitosan saja tidak dapat langsung digunakan karena strukturnya yang sangat rapuh dan mempunyai ketahanan sobek yang rendah (Nasir dkk., 2005). Alginat yang merupakan polianionik dan kitosan polikationik bila dilarutkan pada kondisi yang tepat dapat berinteraksi satu sama lain melalui gugus karboksil dari alginat dan gugus amina dari kitosan sehingga dapat memperkuat kestabilan membran (Kaban dkk., 2006)

Dalam rangka meningkatkan kekuatan mekanik dari membran kitosan dengan alginat, maka ditambahkan bahan campuran dengan polimer lebih hidrofilik seperti PVA. Polivinil alkohol adalah polimer bersifat hidrofilik, elastis, tidak beracun, dan polimer biodegradable (Abdel-Mohsen dkk., 2011). Kombinasi antara PVA dan kitosan dapat digunakan sebagai bahan dasar untuk mempersiapkan membran hemodialisis (Barzin dkk., 2006).

Dari paparan sebelumnya, maka dalam penelitian ini akan dikaji efisiensi membran dengan melakukan transpor kreatinin dengan variasi konsentrasi 70, 100, dan $130 \mathrm{mg} / \mathrm{L}$

\section{Metode Penelitian}

Alat-alat yang digunakan dalam penelitian ini adalah satu rangkaian alat transpor, $\mathrm{pH}$ meter, pengaduk magnet (magnetic stirer), batang pengaduk magnet, neraca analitik, cawan petri, oven, alat pengukur ketebalan, alat penunjang berupa alat-alat gelas, spektrofotometer UV-Vis Shimadzu UV-1800, dan spektrofotometer FTIR 
Shimadzu 8201PC, dan alat pengukur uji tarik regang Strograph VG 10-E.

Bahan-bahan yang digunakan dalam penelitian ini adalah akuades, kitosan, alginat, kreatinin, $\mathrm{CH}_{3} \mathrm{COOH} 0,4 \mathrm{M}$; $\mathrm{NaOH} 1 \mathrm{M}$ dan 0,4 $\mathrm{M}$, asam pikrat $8,8 \mathrm{mM}$, dan PVA $0,1 \%$. Bahanbahan kimia tersebut memiliki kualitas pro analisis (p.a) yang berasal dari Merck.

\subsection{Pembuatan Membran Kitosan-Alginat Tertaut Silang PVA $0,1 \%$.}

Untuk pembuatan membran kitosan-alginat, sebanyak $0,075 \mathrm{~g}$ alginat dilarutkan dalam $25 \mathrm{~mL}$ akuades dan $0,5 \mathrm{~g}$ kitosan dilarutkan dalam 50 $\mathrm{mL}$ asam asetat $0,4 \mathrm{M}$ diaduk hingga homogen. Larutan membran kitosan-alginat yang homogen ditambahkan dengan larutan PVA 0,1 g yang dilarutkan dalam $25 \mathrm{~mL}$ akuades suhu $100{ }^{\circ} \mathrm{C}$, kemudian diaduk. Larutan dipipet sebanyak 10 $\mathrm{mL}$ dan dicetak dalam cawan petri. Larutan diuapkan dalam oven pada suhu $45{ }^{\circ} \mathrm{C}$. Membran dalam cawan petri yang telah kering direndam dengan $\mathrm{NaOH} 1 \%$. Membran dilepaskan dari cawan petri kemudian dicuci dengan akuades dan dikeringkan. Karakterisasi membran meliputi analisis gugus fungsi dengan spektrofotometer FTIR, uji serapan air, dan uji kekuatan tarik-regang.

\subsection{Studi Transpor Kreatinin Menggunakan} Membran Kitosan-Alginat Tertaut Silang PVA $0,1 \%$.

Membran dipasang pada chamber yang memisahkan antara fase sumber dan fase penerima. Dalam fase sumber dimasukkan $50 \mathrm{~mL}$ kreatinin untuk transpor kreatinin dan dalam fase penerima dimasukkan $50 \mathrm{~mL}$ akuades, masingmasing fase telah dilengkapi dengan batang pengaduk magnet lalu diaduk selama 6 jam dengan diatur $\mathrm{pH}$ dengan penambahan larutan buffer $\mathrm{pH} 7,4$ dan untuk tiap 2 jamnya diambil masing-masing $2 \mathrm{~mL}$ sampel pada fase sumber dan fase penerima. Untuk analisis kreatinin, fase sumber dan fase penerima ditambah berturutturut larutan asam pikrat $8,8 \mathrm{mM}$ dalam $\mathrm{NaOH}$ 0,4 M didiamkan 36 menit kemudian konsentrasi kreatinin 70, 100 dan $130 \mathrm{mg} / \mathrm{L}$ dianalisis dengan spektrofotometer UV-Vis pada panjang gelombang maksimum.

\subsection{Analisis Data}

Dari hasil sintesis dan karakterisasi membran kitosan-alginat tertaut silang PVA $0,1 \%$ diperoleh data berupa gugus fungsi, kekuatan tarik dan serapan air. Data tersebut dianalisis secara deskriptif. Dari pengukuran hasil transpor dengan menggunakan spektrofotometer UV-Vis diperoleh data absorbansi dan konsentrasi kreatinin. Dari data tersebut dapat dihitung efisiensi transpor (E) dari konsentrasi kreatinin pada fase penerima $\left(\mathrm{C}_{\mathrm{p}}\right)$ dan fase sumber $\left(\mathrm{C}_{\mathrm{s}}\right)$ (Persamaan 1).

$$
E=\frac{C p}{C s} \times 100 \%
$$

\section{Hasil dan Pembahasan}

Untuk mengetahui telah terjadinya interaksi dan terbentuknya struktur antara kitosan-alginat tertaut silang PVA maka dilakukan analisis dengan spektrofotometer IR terhadap hasil sintesis. Spektra IR disajikan pada Gambar 1 sedangkan interpretasi untuk masing-masing bilangan gelombang disajikan pada Tabel 1 .

Tabel 1. Serapan spektra IR pada membran kitosanalginat tertaut silang PVA 0,1\%

\begin{tabular}{lccccc}
\hline \multirow{2}{*}{ Material } & \multicolumn{5}{c}{ Bilangan Gelombang $\left(\mathrm{cm}^{-1}\right)$} \\
\cline { 2 - 6 } & $-\mathrm{OH}$ & $\mathrm{C}=\mathrm{O}$ & $-\mathrm{CO}$ & $-\mathrm{NH}$ & -COOR \\
\cline { 2 - 6 } & & & & & \\
\hline Kitosan & 3425,58 & 1658,78 & - & 1579,06 & - \\
Alginat & 3425,58 & 1620,21 & 1033,85 & - & - \\
& & & 1442,75 & - & - \\
PVA & 3402,43 & - & 1095,57 & & 1265,30 \\
$\begin{array}{l}\text { Membran } \\
\text { Sebelum } \\
\text { Transpor }\end{array}$ & 3363,86 & 1651,07 & - & - & 1087,85 \\
$\begin{array}{l}\text { Membran } \\
\text { Setelah } \\
\text { Transpor }\end{array}$ & 3394,72 & 1651,07 & - & - & \\
\hline
\end{tabular}




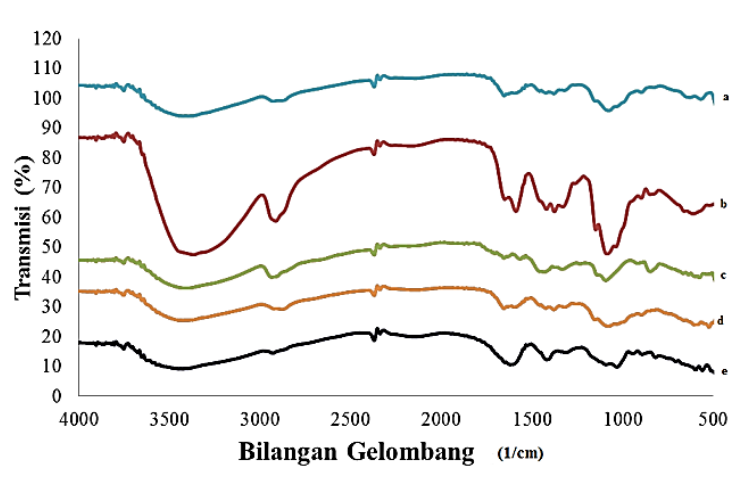

Gambar 1. Spektra IR yang telah digeser vertikal (a) Membran Setelah Transpor (b) Membran Sebelum Transpor (c) PVA (d) Kitosan (e) Alginat

Membran kitosan-alginat tertaut silang PVA disintesis dari pengadukan kitosan dalam asam asetat dan alginat dalam akuades. Dalam suasana asam kitosan membentuk polikationik sedangkan alginat membentuk polianionik. Polikationik dan polianionik akan bereaksi membentuk polielektrolit melalui reaksi ionik (Bernabe dkk., 2005).

Dari Tabel 1 dapat dilihat bahwa untuk analisis spektrum IR PVA pada bilangan gelombang 3402,43 $\mathrm{cm}^{-1}$ menunjukkan regang $\mathrm{OH}$, pada bilangan gelombang $1442,75 \mathrm{~cm}^{-1}$ dan $1095,57 \mathrm{~cm}^{-1}$ menunjukkan gugus $-\mathrm{CO}$. Dari analisis spektrum IR kitosan menunjukkan puncak $3425,58 \mathrm{~cm}^{-1}$ terdapat ikatan -OH (hidroksil), $1658,78 \mathrm{~cm}^{-1}$ dan $1579,06 \mathrm{~cm}^{-1}$ yang masing-masing mengindikasikan keberadaan ikatan $\mathrm{C}=\mathrm{O}$ (stretching) dan ikatan $-\mathrm{NH}$ (stretching). Sementara spektrum IR alginat menunjukkan puncak serapan yang karakteristik untuk ikatan -OH (hidroksil), ikatan $\mathrm{C}=\mathrm{O}$ (karboksil) dan ikatan -CO (karbonil) pada bilangan gelombang masing-masing 3425,58; 1620,21 dan $1033,85 \mathrm{~cm}^{-1}$.

Hasil spektrum IR membran sebelum transpor menunjukkan bahwa telah terjadi pergeseran serapan gugus amino dari kitosan dan gugus karboksil dari alginat pada puncak 1651,07 $\mathrm{cm}^{-1}$ karena terjadinya interaksi ionik antara gugus amino pada kitosan dan gugus karboksil pada alginat (Kaban, dkk., 2006). Pada bilangan gelombang 3363,86 $\mathrm{cm}^{-1}$ intensitasnya melebar karena keberadaan gugus - $\mathrm{OH}$ dari alginat dan PVA (Bernabe dkk., 2005). Penyerapan pada bilangan gelombang 1087,85 dan 1265,30 $\mathrm{cm}^{-1}$ hanya muncul pada spektrum membran, ini dianggap berasal dari gugus ester yang menunjukkan ikatan silang antara alginat dan PVA (Lusiana dkk., 2013). Hasil taut silang ditandai dengan terjadinya pergeseran ke kanan (bilangan gelombang makin rendah=frekuensi vibrasi makin kuat) pada puncak gugus $-\mathrm{OH}$ komponen membran dari 3400-an ke 3300-an $\mathrm{cm}^{-1}$, yang mengindikasikan terbentuknya ikatan hidrogen (Fithriyah dan Redjeki, 2017).

Berdasarkan interpretasi spektra IR tersebut, maka membran kitosan-alginat tertaut silang PVA telah berhasil disintesis. Dari hasil spektra IR terdapat interaksi antara gugus aktif membran dengan kreatinin yang disajikan pada Gambar 2 .

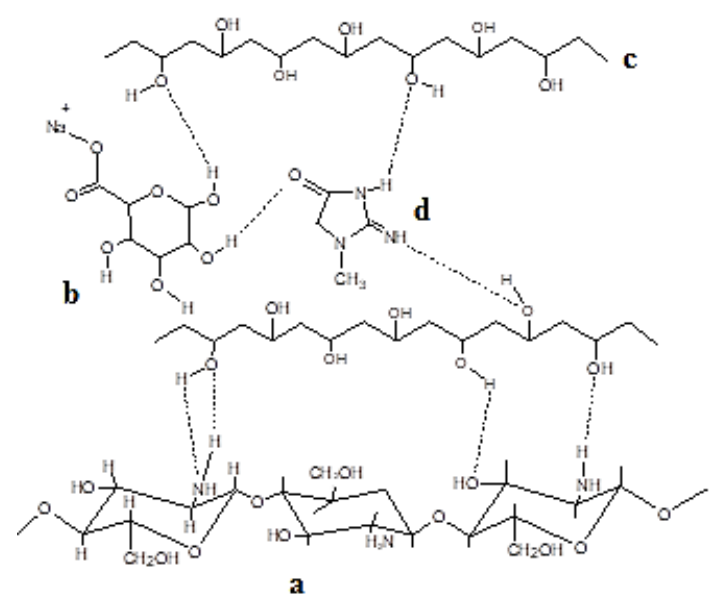

Gambar 2. Prediksi interaksi antara gugus aktif membran (a) kitosan, (b) alginat, (c) PVA dengan (d) kreatinin

Uji serapan air dilakukan untuk memprediksi ukuran zat yang bisa terdifusi melalui materialmaterial tertentu. Dari hasil penelitian uji serapan air pada membran kitosan-alginat PVA selama 6 jam mencapai rata-rata $257,76 \%$. Hasil menunjukkan bahwa membran kitosan-alginat dapat mengembang dalam air dan cukup elastis, sehingga membran ini dapat berpotensi untuk digunakan sebagai membran hemodialisa. Hal ini disebabkan ketika suatu biopolimer kontak dengan cairan, maka terjadinya pengembangan akibat adanya termodinamika yang bersesuaian dan adanya gaya tarik yang disebabkan efek silang yang terjadi pada rantai polimer. Ketika membran mengembang, mobilitas rantai polimer 
bertambah sehingga memudahkan penetrasi pelarut, selain itu ion-ion kecil yang terperangkap dalam membran berdifusi meninggalkan membran sehingga memberikan peluang yang lebih besar bagi pelarut untuk mengisi ruangruang kosong yang ditinggalkan. Pengembangan membran kitosan-alginat kemungkinan disebabkan oleh masih adanya interaksi ionik antara gugus $\mathrm{NH}_{3}{ }^{+}$dari kitosan dan ion $\mathrm{COO}^{-}$ dari alginat membran (Kaban dkk., 2006). Uji serapan air terhadap membran dapat menunjukkan hidrofilitas suatu membran. Semakin banyak komposisi kitosan pada membran akan meningkatkan sifat hidrofilitas membran PVA yang akan meningkatkan jumlah molekul kreatinin yang terdifusi. Paduan antara kitosan dan PVA mempunyai sifat yang tidak rapuh karena terbentuknya ikatan hidrogen yang kuat di antara gugus hidroksil PVA dengan gugus amina atau gugus hidroksil kitosan (Miya dkk., 1984).

Karakterisasi sifat mekanik digunakan untuk mengetahui kekuatan membran terhadap gaya yang berasal dari luar yang dapat merusak membran. Uji regang pada membran dapat dilihat pada nilai tensile strength yaitu nilai tegangan membran pada saat putus dan nilai strain at Fmax yaitu regangan membran pada saat putus. Data hasil uji regang pada membran kitosanalginat PVA disajikan pada Tabel 2.

\begin{tabular}{ccccccc}
\hline $\mathrm{Nr}$ & $\begin{array}{c}\mathrm{a} 0 \\
(\mathrm{~mm})\end{array}$ & $\begin{array}{c}\mathrm{b} 0 \\
(\mathrm{~mm})\end{array}$ & $\begin{array}{c}\mathrm{Lc} \\
(\mathrm{mm})\end{array}$ & $\begin{array}{c}\text { Fmax } \\
(\mathrm{N})\end{array}$ & $\begin{array}{c}\text { Tensile } \\
\text { Strength } \\
(\mathrm{MPa})\end{array}$ & $\begin{array}{c}\text { Strain } \\
\text { at } \\
\text { Fmax } \\
(\%)\end{array}$ \\
\hline $\begin{array}{c}\text { Membran } \\
\text { sebelum } \\
\text { transpor }\end{array}$ & 0,028 & 5 & 30 & 0,3876 & 2,7684 & 14,2413 \\
$\begin{array}{c}\text { Membran } \\
\text { setelah } \\
\text { transpor }\end{array}$ & 0,0325 & 5 & 30 & 2,0141 & 12,5595 & 18,5056 \\
\hline
\end{tabular}

Keterangan :

a0 : tebal $(\mathrm{mm})$

b0 : lebar (mm)

Lc : Panjang awal (mm)

Fmax $\quad:$ tarikan $\max (\mathrm{N})$

Tensile strength: Kuat tarikan (MPa)

Strain at Fmax : Kuat Regang (MPa)
Data menunjukkan bahwa kekuatan tarik membran kitosan-alginat PVA sebelum transpor memberikan hasil yaitu 2,7684 MPa dan untuk membran setelah transpor memberikan hasil terbaik yaitu 12,5595 MPa. Hal ini membuktikan bahwa tingginya konsentrasi kitosan pada membran menyebabkan jarak antar molekul pada kitosan semakin rapat sehingga dapat memiliki kuat tarik yang lebih besar setelah melakukan transpor (Yunianti dan Maharani, 2012). Selain itu peningkatan kuat tarik setelah transpor disebabkan karena efek penguatan jejaring polimer oleh peregangan. Peregangan tautan silang membran karena menyerap molekul pelarut saat transpor dapat menata susunan komponen membran (strain-induced alignment) sehingga lebih teratur dan terikat lebih kuat (strain-induced crystallization) yang dapat menginduksi peningkatan kekuatan (straininduced strengthening) khususnya kuat tarik setelah transpor (Fithriyah dan Erdawati, 2014). Regangan suatu bahan menunjukkan panjang bahan yang dapat ditarik sampai titik putus atau elastisitas. Untuk membran sebelum transpor memiliki elastisitas yaitu $14,24 \%$ dan membran setelah transpor memiliki elastisitas $18,51 \%$. Hal ini menunjukkan bahwa membran setelah transpor mampu menahan gaya yang diberikan dan elastisitas membran dapat menahan zat terlarut pada saat proses transpor sebelum membran putus, dikarenakan dari komposisi membran yaitu PVA yang membuat membran memiliki elastisitas dan kestabilan kimia yang baik. Untuk mengetahui pengaruh konsentrasi kreatinin terhadap hasil transpor dengan menggunakan membran kitosan-alginat tertaut silang PVA dilakukan transpor dengan konsentrasi kreatinin 70, 100 dan $130 \mathrm{mg} / \mathrm{L}$. Membran dibuat dengan memadukan hasil kitosan-alginat tertaut silang PVA untuk transpor kreatinin. Pada transpor membran terfasilitasi (membran yang porinya memiliki gugus aktif), senyawa pembawa memainkan peranan penting. Senyawa pembawa merupakan hal penentu dalam kinerja pemisahan dari fase sumber ke fase penerima. Penentuan konsentrasi optimal dilihat dari transpor kreatininnya. 
Transpor kreatinin dipilih karena berat molekul kreatinin (berat molekul $113 \mathrm{~g} / \mathrm{mol}$ ) yang tinggi dapat dianalogikan dengan ukuran molekul yang besar pula serta kreatinin merupakan tolak ukur dalam kinerja ginjal. Data hasil transpor kreatinin disajikan pada Gambar 3. Hasil penelitian aplikasi transpor menunjukkan bahwa semakin lama waktu transpor maka persentase kreatinin yang tertranspor semakin tinggi. Hal ini menunjukkan adanya perimbangan yang tepat antara gugus hidrofil dengan gugus hidrofob dari membran yang dapat membuat permeasi dari kreatinin meningkat karena adanya gugus amina $\left(-\mathrm{NH}_{2}\right)$ dan gugus hidroksil $(-\mathrm{OH})$ pada kitosan yang dapat membentuk ikatan hidrogen dengan kreatinin (Miya dkk., 1984).

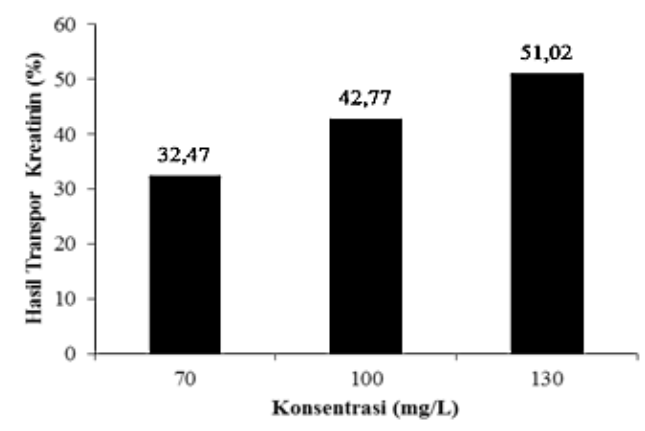

Gambar 3. Grafik hasil transpor membran kitosanalginat tertaut silang PVA $0,1 \%$ terhadap variasi konsentrasi kreatinin $(t=6$ jam $)$

Transpor kreatinin dipengaruhi oleh konsentrasi zat kreatinin dan jumlah dari gugus hidrofob dan gugus hidrofil. Transpor kreatinin dapat terjadi karena adanya gugus-gugus aktif pada membran. Hasil transpor kreatinin pada membran kitosan-alginat tertaut silang PVA dengan variasi konsentrasi 70, 100 dan $130 \mathrm{mg} / \mathrm{L}$ mencapai transpor maksimal pada konsentrasi $130 \mathrm{mg} / \mathrm{L}(51,02 \%)$. Hal ini menunjukkan bahwa semakin tinggi konsentrasi kreatinin maka zat terlarut yang berpindah pada transpor makin tinggi. Hasil transpor optimal pada konsentrasi $130 \mathrm{mg} / \mathrm{L}$ dikarenakan adanya kesesuaian antara banyaknya gugus aktif pembentuk ikatan hidrogen pada senyawa pembawa dengan kerapatan antara gugus aktif senyawa pada membran serta pada variasi konsentrasi kreatinin $130 \mathrm{mg} / \mathrm{L}$. Hal ini diperkuat dengan teori transfer massa yaitu konsentrasi sebanding dengan laju transfer (Hukum Fick) sehingga untuk durasi transpor yang sama konsentrasi yang tinggi akan meningkatkan efisiensi transpor

\section{Kesimpulan}

Hasil transpor kreatinin menggunakan membran kitosan-alginat tertaut silang PVA meningkat dengan meningkatnya konsentrasi kreatinin $(51,02 \%)$. Hasil transpor kreatinin ini lebih tinggi jika dibandingkan menggunakan membran kitosan-pektin (25,24\%) pada konsentrasi yang sama. Berdasarkan hasil penelitian ini disarankan untuk melakukan parameter-parameter pengujian lebih lanjut kemungkinan pemanfaatan membran kitosanalginat tertaut silang PVA sebagai membran hemodialisa.

\section{Daftar Pustaka}

Abdel-Mohsen, A.M., Aly, A.S., Hardina, R., Montaser, A.S., and Hebeish, A., 2011, Biomedical textiles through multifunctioalization of cotton fabrics using innovative methoxypolyethylene glycol-nchitosan graft copolymer, J. Polym. Environ., 20(1), 104-116.

Amiji, M., 1995, Permeability and blood compatibility properties of chitosan n-poly (ethylene oxide) blend membranes for haemodialysis, Biomaterials, 16, 593-599.

Ayuni, N.P.S, Siswanta, D., Suratman A., 2013, Kajian transpor kreatinin menggunakan membran kompleks polielektrolit (PEC) kitosan-pektin, Wahana Matematika dan Sains, 8(2), 77-95

Barzin J., Azizi, H., Morshedian, J., 2006, Preparation of silane-grafted and moisture cross-linked low density polyethylene: part i: factors affecting performance of grafting and cross-Linking, Polym.-Plast. Technol. Eng., 45(8), 979-983.

Bernabe, P., Peniche, C., and Arguelles-Monal, W., 2005, Swelling behavior of chitosan/pectin polyelectrolite complex membranes. Effect of thermal cross-link, Polymer. Bull, 55, 367-375. 
Deppisch, R., Storr, M., Buck, R., Gohl, H., 1998, Blood material interactions at the surfaces of membranes in medical applications, Sep. Purif. Technol., 14(1), 241254.

Fithriyah dan Erdawati, 2014, Mechanical properties of paper sheets coated with chitosan nanoparticle, AIP Conference Proceedings, 1589(1), 195-199

Fithriyah dan Redjeki, 2017, Roles of nanoparticle fillers during nanostructure selfassembly in the enhancement of nanocomposites barrier properties, IMC 2016 Proceedings, 1, (1)

Ignatavicius, W., 2006, Medical Surgical Nurshing Critical Thingking for Collaborative Care $2^{\text {nd }}$ ed., Elsevier Sauders, Ohio

Kaban, J., Bangun, H., Dawolo, A. K., 2006, Pembuatan membran kompleks polielektrolit alginat kitosan, Jurnal Sains Kimia, 10(1), 10 16.

Lusiana, R. A., Siswanta, D. and Hayashita, T., 2013, The Influence of PVA.cl. citric acid/chitosan membrane hydrophicility, Indones. J. Chem., 13(3), 262-270.
Miya, M., Iwamoto, R., and Mima, S., 1984, FTIR study of intermolecular interaction in polymer blends, J. Polym. Sci., Part B: Polym. Phys., 22(6), 1149-1151.

Morti, S., Shao, J., and Zydney, A., 2003, Importance of asymmetric structure in determining mass transport characteristics of hollow fiber hemodialyzers, J. Membr. Sci., 224(1), 1149-1151

Nasir, N.F.M., Zain, N. M., Raha, M. G., and Kadri, N. A., 2005, Characterization of chitosan-poly (ethylene oxide) blends as haemodialysis membrane, Am. J. Appl. Sci., 2(12), 1578-1583

Vanholder, R. C. and Ringoir, S. M., 1992, Adequacy of dialysis: A critical analysis, Kidney Int., 42(3), 540-558

Yunianti, S., dan Maharani, D., 2012, Pemanfaatan membran kitosan-silika untuk menurunkan kadar ion logam $\mathrm{Pb}$ (II) dalam larutan, UNESA: Journal of Chemistry, 1, 108-115. 